\title{
Influence of Silica Fume Content on Performance of High - Performance Concrete
}

\author{
ZHANG Heng-yuan ${ }^{1}$, LIU Xue-ying ${ }^{1 *}$, and WEI Dan-feng ${ }^{2}$ \\ ${ }^{1}$ Zhejiang University of Water Resources and Electric Power, 310018 Hangzhou, Zhejiang, China \\ ${ }^{2}$ Zhejiang Huanlong Environmental Technology Co., Ltd, 324400 Quzhou, Zhejiang, China
}

\begin{abstract}
The influence of different silica fume content on the slump, expansion, compressive strength and flexural strength of high-performance concrete was studied. The results show that with the increase of silica fume content, the slump, expansion, compressive strength, and flexural strength of high-performance concrete show a trend of increasing first and then decreasing. The optimal silica fume content of HPC(Highperformance concrete) is $3 \%$ to $6 \%$.
\end{abstract}

\section{Introduction}

With the rapid development of the global economy, the modernization construction is getting faster and bigger, and the requirements for the quality of the project are getting higher. For the safety of the project and the life extension, the government and experts pay more attention to the high-performance concrete. Due to its high workability, high durability, high volume stability and high strength, high performance concrete has been regarded as the best concrete in the world ${ }^{[1]}$. Highperformance concrete reconfiguration requires low waterbinder ratio, high-efficiency carboxylic acid water reducer, sufficient quantity of high-quality mineral admixtures and raw materials, and well-graded gravel ${ }^{[2]}$. In order to obtain high-performance concrete with good workability and rapid growth in the early stage of the project, a certain amount of silica fume is usually added. Silica powder is collected by special treatment from the fumes escaping from the exhaust gas during the process of smelting industrial silicon at high temperature in an industrial electric furnace. The chemical composition of silicon powder is mainly $\mathrm{SiO}_{2}$, which is composed of extremely fine amorphous spherical particles. The particle size is usually about $0.1 \sim 0.15 \mu \mathrm{m}$, which is two orders of magnitude smaller than cement ${ }^{[3]}$. Small spherical silica fume particles are filled between the cement paste, so that the cementitious material has a better assembly, reducing the harmful pores in the cement paste ${ }^{[4]}$, making the internal structure of the concrete denser and increasing its strength. The specific surface area of silica fume is large, and the free water molecules in the fresh concrete are restricted by silica fume particles, which greatly reduces the amount of bleeding and the accumulation of moisture at the concrete interface, thereby improving the bonding performance of the interface ${ }^{[5]}$. In this paper, the influence of silica fume content on HPC slump, expansion, compressive strength, and flexural strength is studied by mixing different amounts of silica fume.

\section{Experiment}

\subsection{Selection of raw materials}

\subsection{1 cement}

The cement $(\mathrm{C})$ adopts Haolong brand P.O42.5 grade cement, and the measured physical properties of cement are shown in Table 1.

Table1. Cement physical performance index

\begin{tabular}{|c|c|c|c|c|c|c|c|}
\hline \multirow{2}{*}{$\begin{array}{l}\text { Detect } \\
\text { project }\end{array}$} & \multirow{2}{*}{$\begin{array}{c}\text { Ratio } \\
\text { tablear } \\
\text { ea } \\
\left(\mathrm{m}^{2} /\right. \\
\mathrm{kg})\end{array}$} & \multirow{2}{*}{$\begin{array}{l}\text { Pure } \\
\text { pulp } \\
(\mathrm{mm})\end{array}$} & \multirow{2}{*}{$\begin{array}{l}\text { Liquid } \\
\text { ity } \\
(\mathrm{mm})\end{array}$} & \multicolumn{2}{|c|}{$\begin{array}{c}\text { Flexural } \\
\text { strength } \\
\text { (Mpa) }\end{array}$} & \multicolumn{2}{|c|}{$\begin{array}{l}\text { compressivestr } \\
\text { ength (Mpa) }\end{array}$} \\
\hline & & & & $3 d$ & $28 \mathrm{~d}$ & $3 d$ & $28 \mathrm{~d}$ \\
\hline $\begin{array}{c}\text { Test } \\
\text { results }\end{array}$ & 325 & 310 & 280 & 6.4 & 9.2 & 27.3 & 47 \\
\hline
\end{tabular}

\subsubsection{Fly ash and mineral powder}

Grade II fly ash(FA) and mineral powder(MP) produced by Guo Long are used. The physical properties of fly ash and mineral powder are shown in Table 2 and Table 3 respectively. After testing, the indicators meet the national standards of "Fly Ash Used in Cement and Concrete" (GB/T596-2017) and "Granulated Blast Furnace Slag Powder Used in Cement, Mortar and Concrete" (GB/T18046-2017) Indicator requirements. 
Table2. Fly ash physical performance index.

\begin{tabular}{|c|c|c|c|c|}
\hline Test items & $\begin{array}{c}\text { Fineness } \\
(\%)\end{array}$ & $\begin{array}{c}\text { Ignition } \\
\text { loss (\%) }\end{array}$ & $\begin{array}{c}\text { Moisture } \\
\text { content (\%) }\end{array}$ & $\begin{array}{c}\text { Water } \\
\text { demand } \\
\text { ratio (\%) }\end{array}$ \\
\hline $\begin{array}{c}\text { Detection } \\
\text { value }\end{array}$ & 17 & 5 & 0.3 & 103 \\
\hline $\begin{array}{c}\text { National } \\
\text { standard }\end{array}$ & $\leq 30$ & $\leq 8$ & $\leq 1$ & $\leq 105$ \\
\hline
\end{tabular}

Table3. Physical performance index of slag powder.

\begin{tabular}{|c|c|c|c|c|c|}
\hline Test items & $\begin{array}{c}\text { Liquidity } \\
\text { ratio } \\
(\%)\end{array}$ & $\begin{array}{c}\text { Moisture } \\
\text { content } \\
(\%)\end{array}$ & $\begin{array}{c}\text { Ignition } \\
\text { loss } \\
(\%)\end{array}$ & $\begin{array}{c}7 \mathrm{~d} \\
\text { activity } \\
\text { index } \\
(\%)\end{array}$ & $\begin{array}{c}28 \mathrm{~d} \\
\text { activity } \\
\text { index } \\
(\%)\end{array}$ \\
\hline $\begin{array}{c}\text { Detection } \\
\text { value }\end{array}$ & 96 & 0.1 & 0.2 & 90 & 105 \\
\hline $\begin{array}{c}\text { National } \\
\text { standard }\end{array}$ & $\geq 95$ & $\leq 1$ & $\leq 1$ & $\geq 70$ & $\geq 95$ \\
\hline
\end{tabular}

\subsubsection{Silica fume}

Using silica fume(SF) produced by a company in Shanghai, its main chemical composition is shown in Table 4.

Table4. Chemical composition of silicon powder.

\begin{tabular}{|c|c|c|c|c|c|}
\hline Project & $\mathrm{SiO}_{2}$ & $\mathrm{FeO}_{3}$ & $\mathrm{Al}_{2} \mathrm{O}_{3}$ & $\mathrm{CaO}$ & $\begin{array}{c}\text { Ignition } \\
\text { loss }\end{array}$ \\
\hline $\begin{array}{c}\text { Content } \\
/ \%\end{array}$ & 90.5 & 3.0 & 3.1 & $<1.7$ & $<3.8$ \\
\hline
\end{tabular}

\subsubsection{River sand and coarse aggregate}

The river sand(RS) used has a mud content of $0.8 \%$,awatercontent of $4 \%$, an apparent density of $2580 \mathrm{~kg} / \mathrm{m}^{3}$, a fineness modulus of 3.0 , the gradation zone to which this sand belongs is the second zone sand.

The coarse aggregate(CA) particle size required for the configuration of high-performance concrete should not be greater than $20 \mathrm{~mm}$. The crushed stone adopts $5-20 \mathrm{~mm}$ continuous gradation produced by Yangchen, with a mud content of $0.5 \%$, a needle-flaky content of $3 \%$, a crushing index of $6.5 \%$, and an apparent density of $2610 \mathrm{~kg} / \mathrm{m}^{3}$.

\subsubsection{Water reducing agent}

The water reducing agent (WR) adopts the highefficiency polycarboxylic acid water reducing agent produced by Subote Company, the water reducing rate reaches $27 \%$, the $\mathrm{PH}$ value is $6,10.2 \%$ of the solid content.

\subsection{Experimental program}

HPC with a water-to-binder ratio of 0.28 is used as the basic mixing ratio, and $2.0 \%$ carboxylic acid water reducing agent is added to ensure its fluidity. Adding $11.4 \%$ of mineral powder and $8.6 \%$ of fly ash to replace cement to reduce the early hydration heat of concrete. Fixed water-binder ratio and total amount of cementitious materials $(535 \mathrm{~kg})$, using internal mixing method ${ }^{[6]}$, respectively $0 \%, 3 \%, 6 \%, 9 \%, 13 \%, 18 \%, 23 \%$ silica fume, etc. Equivalent replacement cement, a total of 7 sets of mixing ratios are shown in Table 5.

Table5. HPC mix design.

\begin{tabular}{|c|c|c|c|c|c|c|c|c|}
\hline Num & $\begin{array}{c}S F / \\
\%\end{array}$ & $\begin{array}{c}C \\
/ \mathrm{kg}\end{array}$ & $\begin{array}{c}M P / \mathrm{k} \\
\mathrm{g}\end{array}$ & $\begin{array}{c}F A / \\
\mathrm{kg}\end{array}$ & $\begin{array}{c}C A \\
/ \mathrm{kg}\end{array}$ & $\begin{array}{c}R S \\
/ \mathrm{kg}\end{array}$ & $\begin{array}{c}W \\
/ \mathrm{kg}\end{array}$ & $\begin{array}{c}W R \\
/ \mathrm{kg}\end{array}$ \\
\hline $\mathrm{A} 0$ & 0 & 428 & 61 & 46 & 1063 & 652 & 150 & 10.7 \\
\hline $\mathrm{A} 1$ & 3 & 415 & 61 & 46 & 1063 & 652 & 150 & 10.7 \\
\hline $\mathrm{A} 2$ & 6 & 402 & 61 & 46 & 1063 & 652 & 150 & 10.7 \\
\hline $\mathrm{A} 3$ & 9 & 389 & 61 & 46 & 1063 & 652 & 150 & 10.7 \\
\hline $\mathrm{A} 4$ & 13 & 372 & 61 & 46 & 1063 & 652 & 150 & 10.7 \\
\hline $\mathrm{A} 5$ & 18 & 351 & 61 & 46 & 1063 & 652 & 150 & 10.7 \\
\hline $\mathrm{A} 6$ & 23 & 330 & 61 & 46 & 1063 & 652 & 150 & 10.7 \\
\hline
\end{tabular}

\subsection{Experiment method}

\subsubsection{Specimen preparation}

The laboratory mixer can make 20 liters of cement each time. According to the experimental design, the various raw materials are weighed according to 1:0.02, and the big stones and small stones in the coarse aggregate are weighed according to 8:2. First, pour the coarse aggregate and fine aggregate into the mixer, then add 50\% water and stir for about 25 seconds, pour the admixture into it, mix the remaining $50 \%$ water and the water reducing agent, and then slowly pour Into the blender. After testing the degree of slump and expansion, install the mold, vibrate evenly with a vibrator, smooth with a shovel, and then classify and label it. After 24 hours, remove the mold and put it in a standard curing room for curing to the age and take out the test strength. The experiment is carried out according to relevant specifications or standards.

\subsubsection{Testing method}

The fluidity experiment is measured in accordance with the "Standard for Test Methods for the Performance of Ordinary Concrete Mixtures" (GB/T50080-2016). The strength test is determined in accordance with the "Standard for Experimental Methods of Concrete Physical and Mechanical Properties" (GB/T50081-2019). When testing the strength, in order to reduce errors, 3 test blocks are prepared for each age, and calculate its representative value. During the test, if the strength difference between the three test blocks is too large, it may be the result of uneven mixing of the concrete mortar placed in the installation mode or uneven vibration of the mold on the vibrator. The sample needs to be remade for the test. 


\section{Result analysis}

\subsection{The influence of silicon powder content on HPC fluidity}

Figures 1 and 2 show the influence of silicon powder content on HPC expansion and slump.

From the figure, we can see that as the content of silica fume increases, the fluidity and slump of HPC show a trend of first increasing and then decreasing. When the content of silica fume is $0-6 \%$, fluidity and expansion are better than without There is a significant increase in silicon powder, and the fluidity and expansion degree increase the most when the content of silicon powder is $3 \%$. When the content of silica fume is more than $9 \%$, the fluidity is lower than when the silica fume is not added. On the whole, adding a small amount of silica fume HPC is the reason for the increase in fluidity. The small spherical particles of silica fume can fill part of the space between the coarse particles of cement and replace the filling water in the gap. This part of the water can improve the fluidity of the concrete ${ }^{[7]}$. However, because the specific surface area of silicon powder is too large, with the increase of silicon powder content, the water demand increases sharply. While keeping the water consumption constant, the concrete becomes viscous, resulting in a rapid decrease in slump and expansion.

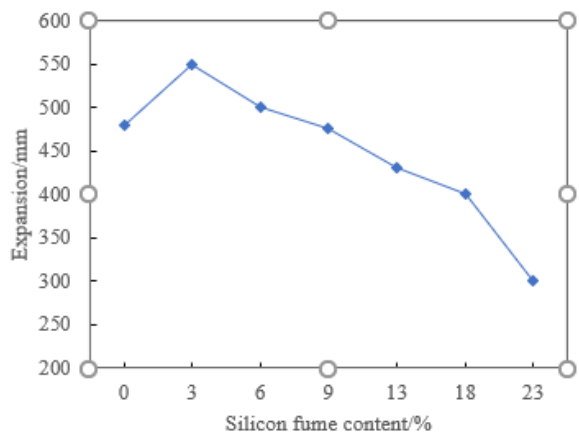

Fig1.. The influence of silica fume content on HPC expansion.

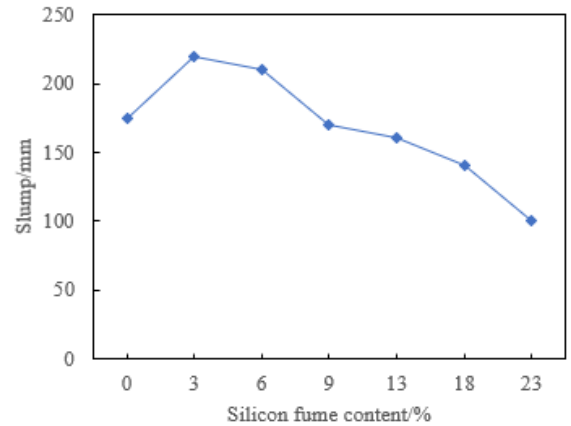

Fig2. The influence of silica fume content on HPC slump.

\subsection{The influence of silicon powder content on the mechanical properties of HPC}

The high-performance concrete test block with $\mathrm{W} / \mathrm{B}=0.28$ is placed in the standard curing room for $3 \mathrm{~d}, 7 \mathrm{~d}, 28 \mathrm{~d}$ compressive strength and $28 \mathrm{~d}$ flexural strength as shown in Figure 3 and Figure 4.

It can be seen from the figure that with the increase of silicon powder content, the compressive strength and flexural strength of HPC show a trend of first increasing and then decreasing. Comparing $\mathrm{A} 0$ and $\mathrm{A} 1$, it can be seen that the $3 \mathrm{~d}$ compressive strength of A1 specimen is $18.46 \%$ higher than that of $\mathrm{A} 0$, the $7 \mathrm{~d}$ compressive strength is increased by $6.5 \%$, and the 28 -day compressive strength is increased by $3.2 \%$. 28 flexural strength increased by $17.93 \%$. It can be seen that after adding a certain amount of silicon powder, the compressive strength and flexural strength of HPC have been significantly improved. On the one hand, because the particle size of the silica fume particles is small, the filling effect is achieved. The incorporation of silica fume reduces the porosity, improves the pore gradation, and reduces the pores larger than $0.1 \mu \mathrm{m}$, making the HPC more compact, reducing internal defects, and improving strength. On the other hand, the key to increasing the strength of concrete with silica fume is to strengthen the bond between cement paste and aggregate. Silica fume has strong pozzolanic properties, and can react with cement hydration product $\mathrm{Ca}(\mathrm{OH})_{2}$ to form a C-S-H gel with higher strength. C-S-H is type III in the early stage and type IV in the later stage. It acts as a skeleton in the cement paste ${ }^{[8]}$, so the strength of HPC is very high. No silicon powder is added to A0, and fly ash is weak in activity, and sufficient $\mathrm{Ca}(\mathrm{OH})_{2}$ is needed to cause secondary hydration. Therefore, the early fly ash does not participate in the cement hydration process. When the age reaches about 7 days, the concentration of $\mathrm{Ca}(\mathrm{OH})_{2}$ in the test block increases, and the fly ash particles slowly hydrate with $\mathrm{Ca}(\mathrm{OH})_{2}$. Generate $\mathrm{CSH}$ gel to increase the strength of concrete ${ }^{[9]}$. Therefore, by adding a certain amount of silicon powder, the early strength of HPC increases rapidly. Adding excessive silica fume, the compressive and flexural strength of HPC decreases because: the increase in silica fume content also increases the water demand. Under the condition that the water consumption remains unchanged, the excess silica fume and incomplete cement hydration lead to the internal HPC Unable to form a whole, internal defects increase and strength decreases. Moreover, adding excessive silica fume will greatly accelerate the early hydration process of cement, and the risk of cracks in the early concrete will greatly increase.

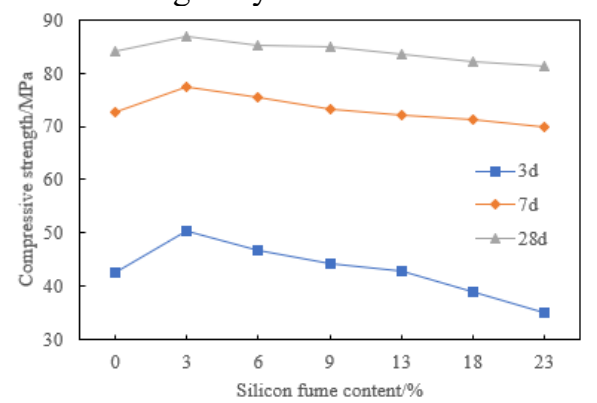

Fig3. Influence of Silicon Fume Content on HPC Compressive Strength. 


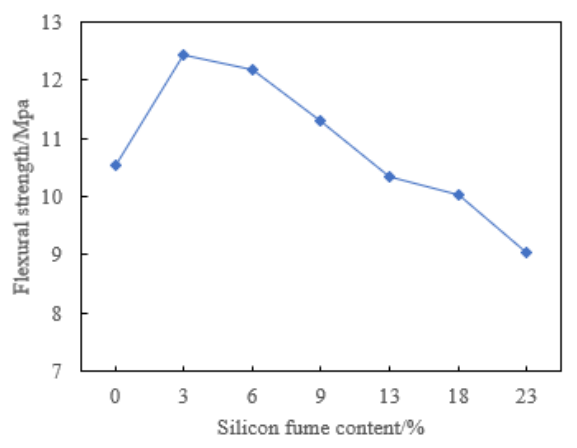

Fig4. Influence of Silicon Fume Content on the Flexural Strength of HPC28d.

\section{Conclusion}

With the increase in the amount of silicon powder incorporated, the slump and expansion of HPC show a trend of increasing first and then decreasing. When the silicon powder parameter is $3 \%$, the HPC slump and expansion reach the maximum.

After HPC is mixed with a certain amount of silicon powder, the compressive strength and flexural strength of HPC will increase first and then decrease. When the content of silicon powder is $3 \%$ to $6 \%$, the strength increase is most significant. When the content of silicon powder is greater than $9 \%$, HPC will have an adverse effect and its strength will decrease accordingly.

Comprehensive workability, fluidity, and mechanical properties, the optimal content of HPC silica fume in this experiment is $3 \%$ to $6 \%$.

\section{References}

1. WANG Man,LI Shiqi \& DING Rui.(2017). Research progress of high performance concrete. Sichuan Cement(07),337.

2. DONG Fangyuan, ZHENG Shansuo \& SONG Mingchen.(2018). Research progress of high performance concrete I: Design method of raw material and mix ratio. Material Guide (01),159-166.

3. MA Shaojun,ZHANG Huili \& DONG Peng. (2005). Mixing technology of high performance concrete with double silica fume and fly ash. China Rural Water Conservancy and Hydropower (04), 64-67+69.

4. CUI Qiwen.(2008). Influence of silica fume on the performance of high performance concrete. Shanxi Architecture(13),193-195.

5. YANG Ping,PENG Zhenbin.(2002).Discussion on Application of Silica Fume in Concrete. Concrete (01), 11-14.

6. GAO Wei,TAI Surong.(2011). Talking about the influence of silica fume on high performance concrete. Brand and standardization (16),49.

7. LI Qingfu,SUN Zhenhua \& ZHANG Haiyang. (2018). Experimental study on the influence of fly ash and silica fume on the strength of concrete. Concrete (05),77-79.

8. LI Luhua,WANG Hailong \& ZHAO Qingkuan.
(2009). Influence of silica fume on high performance of concrete. Shanxi Water Conservancy Technology(03),28-30.

9. YAO Yan,WANG Lin \& TIAN Pei.(2006). High performance concrete. Beijing: Chemical Industry Press, 22-40. 